\title{
The Complex Function of Exercises in a Martime Strategy of Deterrence
}

James H. Bergeron

Exercises occupy a central place in both the theory and practice of naval strategy, and in particular a strategy of deterrence. ${ }^{1}$ They serve complex purposes designed to convey capability and intent to adversaries, assurance to allies, to provide training and force integration for one's own forces, to promote the maritime services to political leaders, or some combination of these. Examining the role of exercises in strategy must ask the question, strategy to what end? This invites a consideration of the overlapping or conflicting purposes of exercises as they relate to different aspects of maritime strategy.

\section{The Changing Focus of Allied Exercises}

In the Cold War, the dominant political and military strategy against the Soviet Union was containment built on deterrence. This was reflected in the great naval exercises of the early Cold War: MAINBRACE, LONG STEP and MARINER. They integrated allied forces, forged bonds of trust between military leaders and tested the early NATO's collective warfighting ability. But notably, the military itself did not speak of these in deterrent terms of signalling capability or resolve. NATO's 1952 internal report on Exercise MAINBRACE is entirely focused on operational lessons learned in how to fight a war. ${ }^{2}$ If deterrence was the political objective, it was absent from how the warfighter at least officially approached the exercise or its meaning.

1 As Professor Beatrice Heuser points out, there is a dearth of literature on the strategic function and effects of military exercises. See Beatrice Heuser, Tormed Heier and Guillaume Lasconjarias (eds.), Military Exercises: Political Messaging and Strategic Impact. Rome, NATO Defence College Forum Paper 26, 2020, 1-4.

2 See S.G 207/3 Report by the Standing Group to the Military Committee on NATO Exercises - 1952, 21 November 1952, 47-50, declassified, available at https://archiv es.nato.int/uploads/r/null/1/1/114838/SG_207_3_ENG_PDP.pdf. 
That operational deterrent focus matured along with the Cold War. No exercise was more focused on sending a deterrent message than the OCEAN VENTURE series developed by US Secretary of the Navy John Lehman, Vice Admiral Ace Lyons and Vice Admiral Hank Mustill in the early 1980s. ${ }^{3}$ As Diego Ruiz-Palmer notes, Ocean Venture was designed precisely to demonstrate to the Kremlin the unmatchable US superiority by threatening Soviet SSBN bastions off the Kola Peninsula. ${ }^{4}$

After the Cold War, maritime exercises reverted again to a focus on training and interoperability in series like MARINER directed by NATO HQ Naval Forces North and South, and by Destined Glory and Midas, directed by Naval Striking and Support Forces South (STRIKFORSOUTH) and later its successor Naval Striking and Support Forces NATO (STRIKFORNATO). Messaging in these exercises was largely internal, signalling commitment to the NATO Response Force, which was created as an instrument of transatlantic burden sharing. Scenarios tended to focus on out-of-area crisis management, counter-insurgency and counterterrorism missions.

BALTOPS is a good example of an allied exercise series changing its purpose over time. Founded in 1971 by the US Navy, it was the largest maritime exercise in the Baltic. In its early years, it showed US willingness to brave the Baltic Sea (a Red or neutral lake at the time) and connect with its allies. But its naval posture was relatively modest and predictable. That changed in the 1980s with the Lehman Maritime Strategy. In BALTOPS 1985, DESRON 14 entered the Baltic with a major show of strength, including a six ship Surface Action Group including the battleship USS Iowa BB-61 and the nuclear-powered cruiser Ticonderoga CG-47..$^{5}$ The first US Navy visit to Poland since 1927 occurred in BALTOPS 1990.

With the end of the Warsaw Pact and the collapse of the USSR, BALTOPS shifted towards the integration of Partnership for Peace nations and later the involvement of Russia as a strategic partner. Scenarios became softer, reflecting the Balkan Wars, the Global War on Terrorism and, after Hurricane Katrina, the 'Global War on Weather'. The 2009 exercise was advertised as 'a joint operation that allows personnel from partner na-

3 See John Lehman, Oceans Ventured, Winning the Cold War at Sea (New York: W.W. Norton \& Co, 2018).

4 Diego Ruiz-Palmer, "Military exercises and strategic intent through the prism of NATO's Autumn Forge exercise series, 1975-1989”, in Military Exercises: Political Messaging and Strategic Impact, eds. Beatrice Heuser, Tormed Heider and Guillaume Lasconjaraias (Rome: NATO Defence College Forum Paper 26, 2020), 88-89.

5 See NavSource Archives at http://www.navsource.org/archives/01/57s.htm. 
tions to prepare for disaster relief efforts, humanitarian assistance and peacekeeping efforts' ${ }^{6}$ Russia joined in several of the BALTOPS exercises, which was always a bit difficult and created the sense they were primarily in there to watch us.

The mood shifted after the 2008 Georgia-Russia conflict. In the 2000s, BALTOPS had conducted amphibious landings in Poland, but in $2010^{7}$ and again in $2012^{8}$, BALTOPS conducted amphibious landings in the Baltic States, the first time ever in former Soviet territory. It was intended as a clear signal of US and Baltic solidarity against Russian aggression.

After 2014 Russia dropped out of BALTOPS, which become flagged as a 'NATO' associated exercise. The trend towards counter-aggression as a focus deepened. STRIKFORNATO became the default Commander, reflecting the NATO role of Commander US Sixth Fleet. In 2019, BALTOPS was commanded by VADM Andrew 'Woody' Lewis, COMSECONDFLT in their first exercise deployment. ${ }^{9}$

BALTOPS 2019 was also notable in being linked to the UK-led BALTIC PROTECTOR deployment and exercise of the Joint Expeditionary Force. ${ }^{10}$ 17 vessels led by HMS Albion participated in joint integration training, joined BALTOPS and then linked up with the British eFP battle group in Estonia to conduct amphibious landings and raids. Its publicity described JEF as 'Willing and able to act without other nations' but 'prepared to work alongside NATO, EU, UN and other Allies'. BALTIC PROTECTOR is politically interesting in signalling the use of exercises to promote coalitions of the willing outside the NATO construct, but presumably to repel aggression in the NATO Area of Responsibility.

Other contemporary maritime exercises worth considering include NORTHERN COASTS, a well-established MCM training event since 2007 that sends a strategic message about keeping open the Danish Straits. The exercise is usually based on a fictitious country making territorial claims in

6 DODLive 16 June 2009.

7 DeFilippis, Rocco, "BALTOPS 10 MPF Operations Kick Off in Latvia", Marines, 8 June 2010, available at https://www.marforeur.marines.mil/News/News-Article-Di splay/Article/520886/baltops-10-mpf-operations-kick-off-in-latvia/.

8 "Allied landing demonstrates crisis response efficiency", The Baltic Times, 13 June 2012, available at https://www.baltictimes.com/news/articles/31379/.

9 Werner, Ben, “U.S. 2nd Fleet Kicks Off BALTOPS 2019”, USNI News, 7 June 2019, available at https://news.usni.org/2019/06/07/u-s-2nd-fleet-kicks-off-baltops-2 019.

10 Eckstein, Megan, "New U.K.-Led Maritime First Responder Force Takes to Sea at BALTOPS”, USNI News, 21 June 2019, available at https://news.usni.org/2019/06/ 21/new-u-k-led-maritime-first-responder-force-takes-to-sea-at-baltops. 
the Baltic Sea, with forces acting under UN mandate. In the realm of antisubmarine warfare, NATO exercises MANTA and MONGOOSE directed by Commander Allied Submarine Forces NATO (COMSUBNATO) for Commander Allied Maritime Command (MARCOM) have grown in importance and quality. Aimed at improving tactical anti-submarine warfare (ASW) performance at the task group level, MONGOOSE practises in the North Atlantic, while MANTA is conducted in the Mediterranean. ${ }^{11}$ These took the place of a number of small allied ASW exercises and NATO's DOGFISH exercise series as financial and fleet size considerations after the Cold War counselled for consolidation. Their recent expansion was also linked to a growing awareness of NATO ASW being practised less and Russian submarine capabilities strengthening.

TRIDENT JUNCTURE 2018 was the largest NATO exercise since the end of the Cold War, involving10,000 tracked and rolling vehicles and major naval deployment, including the Harry S. Truman Carrier Strike Group. ${ }^{12}$ NATO moved 7 brigades in 30 days, all in rough weather, and Russia paid attention. There were, of course, challenges to overcome: troops arrived in summer uniforms and tyres were not fitted for the snow and ice. Most of all, the alliance had months to prepare; this was not a snap exercise or a demonstration of what allies could deliver at short notice. But it was considered a huge strategic communications success among the allies and in terms of messaging to Russia. ${ }^{13}$

11 On Dynamic Mongoose 2020, see https://shape.nato.int/news-archive/2020/dyna mic-mongoose-concludes.

12 Jack Watling, “NATO's Trident Juncture 2018 Exercise: Political Theatre with a Purpose”, RUSI Commentary, 20 November 2018, available at https://rusi.org/com mentary/nato\%E2\%80\%99s-trident-juncture-2018-exercise-political-theatre-purpos e.

13 There have been a series of scholarly and think-tank studies on the modern ASW challenge of a resurgent Russian Federation Navy, beginning with Kathleen $\mathrm{H}$. Hicks, Andrew Metrick, Lisa Sawyer Samp and Kathleen Weinberger, Undersea Warfare in Northern Europe, Center for Strategic and International Studies (Washington: CSIS, 2016), available at https:/www.csis.org/analysis/undersea-warfare-n orthern-europe. See also Magnus Fredrik Nordenman, The New Battle for the Atlantic: Emerging Naval Competition with Russia in the Far North (Annapolis: Naval Institute Press, 2019). 
Assessing the Value of Exercises in Improving Credible Capability

As noted, the value of an exercise to strategy depends on the strategy. Consider first the most typical purpose of exercising: the improvement of interoperability and collective capability.

Do these exercises tend to build capability and integration between participants? At the level of military cooperation, the answer has to be yes, when well-planned, multinational exercises create opportunities for navies to practise things they cannot practically do at home. Indeed, only a few allies can reasonably deploy an entirely national task group for any length of time or at all given current fleet sizes. National skill sets and capability focus areas vary; there are a range of best practices to learn from. These exercises facilitate experimentation and the transfer of knowledge.

It is also true that exercises create bonds of trust and understanding between commanders and their staff, and group pride among crews. They reinforce standard operating procedures and test communication systems and align processes and tactics for things like salvo fires, ASW screens, carrier strike and amphibious operations.

Finally, they tend to bring the potential adversary to us, so we can have a look at them. In the Cold War, one purpose of Lehman's robust exercises was to goad and provoke the Soviets out so that the allies could collect on them and train against them. ${ }^{14} \mathrm{~A}$ forceful Russian response may have given some politicians pause, but for the navy at the time, it was an opportunity. This begs a critical issue: the alignment of rival military and political cultures and paradigms. It is arguable that exercises had their strongest deterrent effect when the political and military cultures of the US and USSR were aligned on both sides. Thus, a military posture was also a political posture and seen as such; more so when both sides' military and political leaders assumed that war was a serious possibility.

But accepting that well-planned and well-run exercises support naval training and group confidence, and provide intelligence collection opportunities, do such exercises add to NATO's deterrent posture, and if so, by how much? That is a more difficult question, as it requires us to first weigh the value that exercises add to collective alliance maritime capabilities, a foundation of deterrent posture. It is arguable that the mere fact of assembling ships at sea and conducting basic drills has a small deterrent effect, but it is likely to be small. If those exercises are conducted without accompanying and expressed political intent or a political message (and most are

14 See Lehman, Oceans Ventured, 121-125. 
not), then the routine exercise cycle may do more to preserve peace by signalling no intent to challenge an adversary and no escalation of presence outside seasonal norms. That is not strictly deterrence, but more like confidence building. ${ }^{15}$

The same could be said of involving rivals in the more routine allied or NATO exercises. But beyond confidence building, there might even be an argument for deterrence through including rivals in such exercises if we rethink the concept a bit. Classical deterrence focuses on costs imposed by the threat of kinetic means. But including rivals in exercises raises the diplomatic and political costs of acting in a way that would rupture the defence relationship. As the Crimea demonstrated, this is not likely to trump more vital national interests. But it is a cost, nonetheless.

In NATO, the first building block of alliance maritime capability are the exercise programmes designed to create trained and ready, integrated maritime task groups for the NATO Response Force in the NATO Response Force (NRF) rotation cycle. ${ }^{16}$ To answer the question of deterrent value for the NRF, we need to consider several factors:

First, the impact of the exercise series on the task group commander and staff. How long will the command staff remain in post after the exercise? The rate of staff depopulation will determine the residual value of each exercise for that specific task group. Second, the extent to which exercise objectives test vital war fighting skills at task group level, not individual ship level. There was some tendency in prior years for exercises to quietly be more about individual ship workups than advanced task group operations such as joint salvo exercises, multi-ship ASW and fifth-generation fighter support of amphibious assaults. Third, of the objectives we have set, how

15 Although not the topic of this paper, the question of the deterrent efficacy of 'routine' exercises raises a parallel issue of the efficacy of operational deployments aimed at deterrent presence. The question arises of when considering what posture NATO or allied forces should adopt in the vicinity of potential adversary exercises like ZAPAD, or major deployments such as the KUZNETSOV Battle Group deployment of 2016. Similar dynamics apply: if that presence is token, it sends a signal that we are watching and that has value. It contests maritime geographic claims to primacy and that has value. But whether it is deterrence needs a better analysis. It might also be a form of confidence building in that we are responding in the expected way, with a typical scale of forces.

16 See generally 'NATO Response Force', NATO, available at https://www.nato.int/c ps/en/natohq/topics_49755.htm. For a discussion of maritime preparation, see 'France takes the maritime command of the NATO response force', Ministère des Armées, 28 June 2010, available at https://www.defense.gouv.fr/marine/content_en glish/latest-news/france-takes-the-maritime-command-of-the-nato-response-force. 
many were missed because of operational defects in the task group and the Standing Naval Force (SNF)? And how many were missed because nations withdrew their assets from the exercise for another task? Critically, fourth is the correlation between the exercise task groups and the ships that will remain in the SNF after the exercise. While guests dropping into the Standing NATO Maritime Groups (SNMGs) for the sake of the exercise are welcome, that should not take the place of stable manning of the SNF. Historically, the percentage of ships remaining in the SNMGs after an exercise can drop rapidly. Those skills get dispersed across national fleets, which has its own value but is not the same as a well-trained and ready SNF.

The second building block of alliance maritime deterrent capability provided by exercises is their impact on a trained and interoperable alliance fleet as a whole. The first factor to consider in assessing this is the dispersion ratio of crews onboard participating ships. How much of the crew will be veterans of the exercise the next time that ship is in a major NATO exercise? How long is the ship considered NATO-trained? A second factor is the ratio of ship exercise participation to fleet size. Smaller navies mostly do better here; less so the larger ones. How much does the exercise experience gained transfer to the national fleet? This raises interesting questions of the employment of the same national naval assets in multinational exercises, creating a sub-fleet of very experienced ships. That is a rational choice, but of most value to NATO if it is those ships that are ultimately committed to the SNF or deployed in a crisis. Finally, there is the percentage of navy personnel who have had formative allied exercise experiences throughout their careers across individual navies and across the alliance fleet. What is the overall dispersion of experience? A viable pan-NATO exercise programme would ideally achieve a credible level of training for the NRF task groups on deployment, those to be on call, for the national and alliance fleet as a whole, and for the 'alliance crew' as a whole.

\section{Assessing the Deterrent Value of Exercises}

Looking beyond the role of exercises in advancing allied maritime capability, there is the direct relevance of exercises in assuring allies and deterring potential adversaries to consider. To begin with assurance, there is a strong argument that exercises have a high assurance value, although to some extent this could be predicated on the appearance of capability rather than hard or proven capability itself. It is valuable to navies to be seen as valued operational partners by their allies. It is also useful politically for individu- 
al governments in selling their alliance policy to their public. Political leaders applaud these benefits as a visible demonstration of matériel capability, which it is, and implicitly of political resolve, which it is to a more limited degree. A final consideration is that these are self-created metrics of assurance value. Demonstrations of assurance tend to focus on what we have deployed, our presence, not what the rival has in their order of battle, or their presence. That comparative dimension takes us out of the realm of assurance and into deterrence.

We often say that large exercises show resolve, and to a degree they do, but the resolve they show is the resolve to hold that exercise. It is what it is. Resolve in peacetime is a different situation from that in a crisis. And this is particularly so where military posturing is not equated with political resolve by the other side. The act of putting lots of ships and aircraft together with lots of preparatory time is not an accomplishment in deterrent terms unless both sides think that the time frame or the scale of effort was meaningful; or where the adversary could not mount the same posture and exercise in the same time frame and that time frame is moreover relevant to the strategic situation. Speed of response does have deterrent value if executed within a meaningful response time. There is also the factor of normalisation. Each exercise is not writing on a blank sheet of paper. After more than 40 years of BALTOPS, there would be a serious impact if one exercise were skipped. Each becomes part of a deterrent equilibrium.

A second factor commonly associated with exercises and deterrence is geography. Where a naval exercise happens is often as important as the capabilities demonstrated or the size of the assembled force. The early Cold War exercises took place in locations the allies expected to defend: in the North Atlantic and the Mediterranean. In the 1980s, geography expanded to where the allies intended to press their advantage: in the Norwegian Sea and the Baltic. The geographic location of an exercise is a form of peacetime political resolve to claim spheres of primacy or influence or to signal willingness to challenge a vital adversary security zone, such as the Russian SSBN Arctic Bastion.

The relationship between deterrence and exercise geography is complex. Does deploying a few frigates to sensitive waters, which historically provokes a rival, add to deterrence? There are arguments on both sides. Such deployment signals that the deploying powers are not themselves deterred from venturing into those waters in peacetime. That does not create new capabilities to deter or dissuade, but it does show a kind of resolve to compete for access and presence, where a potential adversary has a proprietorial attitude towards its nearby waters. By way of contrast, OCEAN VENTURE arguably did deter in its combination of sizeable deployment 
and demonstration of deception techniques in threatening vital Russian strategic assets in sensitive geography. ${ }^{17}$ It is worth noting that this also raised critical issues of escalation, which are addressed below.

Finally, there is the value proposition of implicit and formal public exercise messaging within a strategic communications paradigm, and here the impact of exercises may indeed be greater than expected. What if the playing field of deterrence for both sides were the communications media and public perception? One might argue that TRIDENT JUNCTURE 2018 was as much about signalling capability and having capability ${ }^{18}$. It was meant to impress and it did impress, in a TV news kind of way. Now-and this is the critical point - if the potential adversary thinks the same way, then this way of playing the deterrent game can have real deterrent effects. We do have some indications that the Russians also enjoy putting on a good naval show for the world and for their own public. One challenge in exercise signalling is the reluctance to publicly tie an exercise to an intended deterrent signal against a given party. Such exercises are almost universally characterised as routine, already scheduled and having nothing to do with the rival that the exercise partly exists to signal to.

\section{Deterrence Management of Exercises}

The emerging field of deterrence management brings together these various factors to calibrate an exercise strategy of deterrence. A lot of thinking lately has gone into how institutions and headquarters conduct deterrence management, and much of this has to do with the scheduling and planning of exercises. This work is still at an early stage, but some lessons are becoming clear on what makes sense and what might need to be refined.

As noted, a preliminary question is what the strategy seeks to do. The notion of Great Power Competition is much in vogue these days. This idea has its flaws; it hides as much as or more than it elucidates. It is also at odds with fundamental political notions of solidarity and mutual respect among allies, and perhaps norms of diplomatic relations more broadly. At its crudest, Great Power Competition implies that there are only a few important pieces on the chessboard and that the rest are pawns in the game, possibly to be traded, which is very transactional, very Trumpian if taken too literally. But in a broader and more principled sense, systemic competi-

17 See Lehman, Oceans Ventured, 85-87.

18 See Watling, "NATO's Trident Juncture 2018 Exercise". 
tion does exist over values, ways of life and the success of political and economic models. Therefore, are we deterring or competing, and if it is the latter, over what? This question matters for deterrent strategy. This analysis will assume that, in terms of the Russian challenge, we are deterring in the classical sense. One might give a different answer when discussing China.

First, what is it that we are measuring in exercise deterrence management? Deterrence is a combination of capability and political will as perceived by an adversary. One entry level problem is likely to be the inability to overtly measure allied solidarity and political will. So half the equation is often missing to begin with. Then we need to be able to assess the credible capability that the alliance possesses, both in reserve and deployed. That ought to be more than just raw numbers of ships and their capabilities, as described in Janes, but even that might be a step in the right direction. A further option is to count numbers of exercises in a span of time, or numbers of personnel involved in the exercise. That has a very nebulous relationship to deterrent posture from a rival's perspective. A moment's reflection on what we pay attention to when they deploy provides a clue: the numbers of advanced offensive platforms, their range arcs, where they are and how concentrated they are. Proximity to joint supporting forces is also important. Counting auxiliaries and logistics vessels makes sense when factored for that purpose, but we need to be clear about what we are measuring.

Then come the problems of deterrence theory and psychology. First, are we in a deterrent situation at all? Is the potential adversary really like a coiled tiger, ready to pounce the moment we take our eyes off the ball? Or are there no current disputes which could escalate to the point where an adversary would be tempted to use force or be seized by an overriding fear that we will? If neither is true, there is arguably nothing to deter and thus measuring deterrent effect is difficult. That does not mean that the demonstration of deterrent capability through exercises is meaningless; this has to happen in peacetime to influence political decisions in a crisis. But the deterrent effect does not occur now, but later.

If we are in a current deterrent dynamic with a hot issue on the table, then the hard question gets begged: What exercise posture deters better: a passive posture, a predictably robust posture, or an unexpectedly robust and forward posture? Conversely, does a modest posture de-escalate or invite adventurism by displaying weakness? There is often a sense that deterrence management is about maintaining an Aristotelian golden mean between extremes. We talk of 'peaks of activities' and 'troughs' but their implications are not sufficiently theorised. Our instincts seem reasonable to $u s$, as satisfied status quo powers. But does an exercise deliver a deterrent ef- 
fect from a rival's perspective? That's the perspective that ultimately matters.

A consideration of deterrence via exercises usually leads to a consideration of the risks of escalation. They are parallel concepts, carrying heavy historical baggage. The problem is that they attempt to characterise the same activity and there is some confusion in their usage. How can one tell a deterrent posture from an escalatory one? As noted, the scale, location and intent of the exercise are critical, as is its regularity in the annual exercise calendar and the current geostrategic situation. Assessment here is complex, and doubly reflective: we need to make the judgement but can only do so by putting ourselves in the place of the 'Man on the Kremlin Omnibus' and making a call about what he would consider truly threatening. Note that, by definition, this will be different from what a rival says publicly.

The inverse of the escalation issue is the lower limit of efficacy in a deterrent strategy. Deterrence is often asked to bear a greater load than it can: deterring war and aggression is the core stuff of military posturing, including exercises. But deterring less than that-things under the threshold of military confrontation, like terrorist, hybrid or grey-zone activity-is more problematic.

An effective allied deterrent posture requires coordination, which is difficult to achieve when individual allies conduct individual or small group coalition exercises or deployments, sometimes in geographically sensitive territory. It is often said that the Kremlin does not distinguish between allied national actions and NATO actions. If that is true, it places a premium on inter-allied coordination of exercise plans and deterrent posture, governed by an overarching deterrent management process. This is not a demand for NATO to run the entire allied exercise programme; the flexibility provided by individual allied efforts has always been valuable in acting as a leading edge for policy and posture development, from OCEAN VENTURE to BALTIC HOST. But that works effectively where there has been solid coordination at the national and NATO levels, so that surprises are avoided and messaging is prepared.

Finally, there are financial and pragmatic matters to consider. Strategic situations can change rapidly. This places strategists and political advisors in a difficult position, especially if they have to counsel that a major exercise is no longer a good idea months after monies and forces have been committed, troops moved, strike aircraft are in place, the B52s are in 
Mildenhall waiting to fly and exercise staff have spent thousands of hours in scripting injects and planning the distinguished visitors day.

\section{Works Cited}

DeFilippis, Rocco, "BALTOPS 10 MPF Operations Kick Off in Latvia", Marines, 8 June 2010, https://www.marforeur.marines.mil/News/News-Article-Display/Arti cle/520886/baltops-10-mpf-operations-kick-off-in-latvia/.

Eckstein, Megan, "New U.K.-Led Maritime First Responder Force Takes to Sea at BALTOPS”, USNI News, 21 June 2019, https://news.usni.org/2019/06/21/new-u-k -led-maritime-first-responder-force-takes-to-sea-at-baltops.

Heuser, Beatrice, Heier, Tormed and Lasconjarias, Guillaume, eds. Military Exercises: Political Messaging and Strategic Impact. Rome, NATO Defence College Forum Paper 26, 2020.

Lehman, John. Oceans Ventured. Winning the Cold War at Sea. New York: W.W. Norton \& Co, 2018.

NATO. S.G 207/3 Report by the Standing Group to the Military Committee on NATO Exercises - 1952, 21 November 1952, declassified, https://archives.nato.int/upload s/r/null/1/1/114838/SG_207_3_ENG_PDP.pdf.

Ruiz-Palmer, Diego. "Military exercises and strategic intent through the prism of NATO's Autumn Forge exercise series, 1975-1989". In Military Exercises: Political Messaging and Strategic Impact, edited by Beatrice Heuser, Tormed Heier and Guillame Lasconjarias, 65-92. Rome: NATO Defence College Forum Paper 26, 2020.

The Baltic Times. "Allied landing demonstrates crisis response efficiency", 13 June 2012, https:/www.baltictimes.com/news/articles/31379/.

Watling, Jack. 'NATO's Trident Juncture 2018 Exercise: Political Theatre with a Purpose', RUSI Commentary, 20 November 2018, https://rusi.org/commentary/n ato\%E2\% $80 \% 99$ s-trident-juncture-2018-exercise-political-theatre-purpose.

Werner, Ben. “U.S. 2nd Fleet Kicks Off BALTOPS 2019”, USNI News, 7 June 2019, https://news.usni.org/2019/06/07/u-s-2nd-fleet-kicks-off-baltops-2019. 